\title{
TOXIC EFFECTS OF GENTAMICIN ON THE KIDNEY AND THE PROTECTIVE VALUE OF NIGELLA SATTVA SUPPLEMENT IN ADULT MALE ALBINO RATS
}

\author{
BY \\ Hoda Ragab Elsayed and Zeinab A. El-Rehim* \\ Departments of Forensic Medicine and Clinical Toxicology and Histology* \\ Faculty of Medicine, Zagazig University
}

\begin{abstract}
Gentamicin (GM) is an effective antibiotic against severe gram-negative infections. However it can produce nephrotoxicity in human. The Nigella sativa (NS) oil has been subjected to several investigations that have revealed its antioxidant activity in different conditions. The ain of this study is to assess the toxic effects of GM on the kidney and the protective value of nigella sativa oil supplementation against gentamicin toxicity. Sixty rats were equally divided into 6 groups: Group I (-ve control group), Group II (Saline group), Group III (Corn oil group), Group IV (NS group), Group V (GM group) and Group VI (GM+NS group). The period of the study extended for 10 days. In the last 24 hours, urine was collected to estimate urinary protein excretion. Then, the rats were sacrificed for biochemical analysis (blood urea nitrogen, creatinine, superoxide dismutase and catalase) and renal histopathology by light and electron microscope. The results of this study showed no significan difference between the negative control, saline, corn oil and NS groups in all measured biochemical parameters. However, there was significant difference in these measured biochemical parameters between GM group and the negative control group. Furthermore, there was significant difference between $G M+N S$ group and GM group. Light microscopic examination of kidney specimens of the rats of GM groups showed proximal tubular degeneration, necrosis, desquamation in epithelial cells of the proximal tubules, disturbed architecture and inflammatory in. filtrate. However, the electron microscopic examination of the same rats revealed defailed histopathological changes that help in explanation the mechanism of toxicity of this drug. The co adininistration of NS with GM revealed marked improvement in histopathological changes of kidney by light and electron microscopic exanination. It was concluded that gentamicin has toxic effects on kidney, and the use of nigella sativa in combination with gentanicin could aneliorate its toxicity.
\end{abstract}

\section{INTRODUCTION}

Gentamicin (GM) is an aminoglycoside antibiotic that is very effective in treating life-threatening gram-negative infections
(Ho and Barza, 1987; Karahan et al., 2005). It has high antibacterial efficacy, rapid onset of action, low rate of true resistance and low cost. However, therapeutic doses of gentamicin can cause nephrotoxicity, 
and it is among the most common causes of acute kidney injury (Safa et al., 2010).

Gentamicin induced nephrotoxicity is characterized by direct tubular necrosis, which is localized mainly in the proximal tubule (Pedraza-Chaverri et al., 2003). It was also reported that the renal toxicity of gentamicin had no morphological changes in glomerular structures (Cuzzocrea et al., 2002). Gentamicin undergoes more extensive accumulation in kidneys, and it is trapped by cells of renal cortex via different mechanism (Wiland and Szechcinski, 2003). The real mechanism by which gentamicin -induces nephrotoxicity is unknown; however, GM has been shown both in vitro and in vivo studies to enhance the generation of reactive oxygen species (ROS) (Morales et al., 2002; Yanagida et al.,2004; Karahan et al., 2005). Ali (2003) stated that ROS are important mediators of gentamicin-induced apoptosis. In addition, GM is known to cause deficiency in intrinsic antioxidant enzymes (Maldonado et al., 2003).

Nigella sativa (NS), an annual herbaceous plant, have been used for the treatment of various diseases (Phillips, 1992). Recently, many therapeutic effects of NS extracts have been documented, including antioxidant effects in both clinical and experimental studies (Burits and Bucar, 2000). Accordingly, among the main approaches used to ameliorate GM-induced. nephrotoxicity is the use of agents with powerful antioxidant properties. Several recent studies have reported that the oil of NS or its components may be useful in ameliorating signs of GS nephrotoxicity (Ali, 2004; Ahmed and Nagi, 2007).

The aim of this study is to assess the toxic effects of gentamicin on the kidney and the protective value of nigella sativa oil supplementation against gentamicin toxicity.

\section{MATERIAL AND METHODS}

\section{Drugs:}

1. Gentamicin sulfate was obtained from Memphis Co. for Pharm. and Chem. Ind. Cairo- Egypt Under authority of Schering-Plough Corporation/U.S.A. It was in the form of ampoules called garamycin, each contains $40 \mathrm{mg}$ gentamicin sulphate, aqueous solution. It was given intraproteineal in a dose of $67.4 \mathrm{mg} / \mathrm{kg} \mathrm{bw}$ that equal to $1 / 10$ of LD50 of gentamicin sulphate ( $674 \mathrm{mg} / \mathrm{kg} \mathrm{bw}$ ) (Robbins et al., 1971). As a point of reference, the gentamicin dosage range that is typically used in rodents to simulate clinical gentamicin toxicity is $40-120 \mathrm{mg} / \mathrm{kg} 7-10$ days (Zager, 2007).

2. Nigella sativa seed oil: Baraka capsule each contain $450 \mathrm{mg}$ of nigella sativa seed oil, manufactured by Technopharma Egypt. It was given by oral gavage in a 
dose of: $2.88 \mathrm{ml} / \mathrm{kg}$ in $2 \mathrm{ml}$ corn oil (Zaoui et al., 2002).

\section{Experimental Design:}

Sixty adult male albino rats weighing 150-200 gm were obtained from the Animal House of the Faculty of Medicine, Zagazig University. The rats were kept in cages made of galvanized zinc plates and fed on basal food containing all rat's requirements. They were divided into six groups each of ten rats, the experemints was extended for 10 days:

Group I (-ve control group): The rats were given only the basal diet and water to determine the basic values of the tested parameters.

Group II (Saline group): The rats were given daily $0.5 \mathrm{ml}$ isotonic saline by intraperitoneal injection.

Group III (Corn oil group): The rats were given daily $2 \mathrm{ml}$ corn oil by gastric gavage, which is the vehicle of NS.

Group IV (NS group): The rats were given daily $2.88 \mathrm{ml} / \mathrm{kg}$ of nigella sativa oil in $2 \mathrm{ml}$ com oil by gastric gavage.

Group V (GM group): The rats were given daily $67.4 \mathrm{mg} / \mathrm{kg}$ bw of gentamicin in $0.5 \mathrm{ml}$ isotonic saline intraperitoneally.

Group VI (GM+NS group): The rats were given GM and NS in the same previous doses simultaneously.
Methods:

\section{- Biochemical Studies}

Urinary protein excretion in 24 hours:

Rats were placed in metabolic cages (figure 1); urine was collected in the last 24 hours of the study (tenth day). Protein concentrations were measured using the method described by Nishi and Elin (1985)

\section{Blood urea nitrogen and creatinine:}

After light anesthesia with ether inhalation, the blood was collected from the retro orbital plexus in a test tube and left to clot then centrifuged at $3000 \mathrm{rpm}$ for 15 minutes. The clear sera were separated for determination of blood urea nitrogen (BUN) and creatinine. Blood urea nitrogen was measured according to the method of Kaplan, (1965). However, creatinine was determined using the method described by Bonsens and Taussky, (1945).

\section{Oxidative Stress Biomarkers in Renal}

\section{Tissues:}

After sacrificing the animals, the enzymatic activity of renal superoxide dismutase (SOD) was assessed in kidney homogenate by following the method described by Marklund, (1985). The catalase activity (CAT) was estimated in the rat kidney tissue according to the method of Claiborne (1985).

\section{- Light microscopic study:}

Kidney specimens were taken and paraffin blocks and sections were prepared, 
stained with Hematoxyline and Eosin and subjected to histological examination by following the method described by Bancroft and Stevens (1996).

\section{- Electron microscopic study:}

Specimens taken from the kidney for electron microscopic study were, immediately fixed in $2.5 \%$ phosphate-buffered glutaraldehyde at $\mathrm{pH} 7.4$ for 2 hours at $4^{\circ} \mathrm{C}$. Post fixed in $1 \%$ osmium tetroxide in the same buffer for one hour at $4^{\circ} \mathrm{C}$ and dehydrated with graded ethanol. Speci mens were embedded in dried Gallatin capsules using fresh resin at $60^{\circ} \mathrm{C}$ for 24 hours (Glauert and Lewis 1998). Sections one micron thick (semi thin section) were obtained using lecia ultracut, stained with toluidine blue and examined at light microscope. Ultrathin sections were made, mounted on copper grids, stained with uranyl acetate and lead citrate and examined with JEOL-JEM 1010 electron microscope in Histology Department, Faculty of Medicine, Zagazig University.

\section{- Statistical analysis:}

The collected data of blood urea nitrogen, creatinine, total protein $/ 24 \mathrm{hs}$, SOD and CAT levels were expressed as mean \pm $\mathrm{SD}$. These data were statistically evaluated using Epi-info program, version $6.02 \mathrm{com}$ puter packages (Dean et al., 1994). Testing methods included one-way analysis of variance (ANOVA) for comparisons be- tween more than two groups followed by least significant difference (LSD) test for comparison between two groups. P-values of $\leq 0.05$ were considered to indicate statistical significance.

\section{RESULTS}

\section{- Biochemical results:}

All measured biochemical parameters showed no significant difference between the -ve control, saline and corn oil groups $(P>0.05)$ (table 1). Therefore, the -ve control group was used for comparison with other groups of the study. Concerning all biochemical parameters, the comparison between -ve control, NS, GM and GM+NS groups revealed statistical significance $(P<0.05)$ (table 2). There was no significant difference between -ve control and NS groups in all studied parameters $(P>0.05)$. The GM group showed significant difference when compared with the -ve control and NS groups. In spite of, the level of all measured parameters in the combined $\mathrm{GM}+\mathrm{NS}$ group approximated to that of -ve control and NS groups. The statistical analysis still showed significant difference $(\mathrm{P}<0.05)$ in all parameters except CAT level which revealed insignificant decrease $(P>0.05)$. However, the comparison between this combined GM+NS and GM groups revealed significant difference $(P<0.05)$ in all studied parameters (table 3). 
- Light microscopic results:

Examination of renal sections from the -ve control group showed normal glomeruli and convoluted tubules (figure $2,3)$. Also, the renal sections obtained from NS groups revealed similar normal structures as that of -ve control group. In sections from the kidneys of GM groups, the proximal convoluted tubules displayed vacuolar degeneration, necrosis and apoptosis with desquamation of epithelial cells. The lumens of these tubules were filled tubular debris. Furthermore, hyaline casts in tubular Iumen, tubular brush border loss and severe inflammatory infiltrate in the form of mononuclear cells were also observed (figure 4, 5). These gentamicininduced pathological lesions were remarkably reduced by the application of nigella sativa as shown in figure (6), where some tubules were lined with cuboidal cells with vesicular nuclei and other destructed tubules were also noticed.

\section{- Electron microscopic results:}

Ultra structure examination of kidney specimens from -ve control rats revealed normal proximal convoluted tubules with regular arranged brush border. The lining epithelial cells showed large euchromatic nucleus and abundant mitochondria that located close to cell membrane. The cells rest on thin basal membrane (figure 7).

Ultra structure of NS given rats was normal as that of -ve control group. Exam- ination of renal sections from rats of GM group showed marked changes in the cells lining the proximal convoluted tubules. There was focal destruction of apical villi. The cytoplasm exhibited multiple vacuoles and lysosmal dense bodies of variable sizes. Mitochondria appeared degenerated and disorganized. There was exfoliated cells appeared in the lumen. Some convoluted tubules were dilated and showed loss of microvilli with cellular debris in the lumen. The cells appeared atrophied with marked cellular destruction resting on thick basement membrane. Some cells revealed electron dense apoptotic nucleus (figure 8,9 and 10).

The specimens of combined $\mathrm{GM}+\mathrm{NS}$ had given rats showed improvement in the induced pathology. The proximal convoluted were lined with low cuboidal cells with euchromatic nucleus, long apical microvilli and many electron dense mitochondria (figure 11).

\section{DISCUSSION}

Gentamicin is a cheap, important and widely-used antibiotic of aminoglycoside for the treatment of Gram-negative bacterial infection. But nephrotoxicity is the main side effect that seriously limits its use (Juan et al., 2007).

The seeds or oil of Nigella sativa, commonly known as black seed or black cu- 
$\mathrm{min}$, have been used as a natural remedy for a number of diseases and conditions. Modern toxicological studies have demonstrated that crude extracts of the seeds and some of its active constituents might have a protective effect against nephrotoxicity and hepatotoxicity induced by either disease or chemicals (Ali and Blunden, 2003).

In the current study, BUN and serum creatinine levels were augmented after GM injection. In addition, the urinary protein excretion/ 24 hours was increased indicating tubular damage. This impairment in renal function was accompanied by a decrease in tissue SOD and CAT that indicate oxidative stress.

Consistent with these results, many studies (Pedraza-Chaverrí et al., 2003; Silan et al., 2007; Soliman, et al., 2007) have shown that GM produced an elevation in the concentrations of biochemical indicators of kidney function such as BUN, serum creatinine and total protein excretion in urine. Several investigators (Atessahin et al., 2003) reported the evidence of GM induced nephrotoxicity by the reduction in renal functions which is characterized by an increase in serum creatinine and serum urea level. These alterations in biochemical parameters are in accordance with the result of the present study.

The exact mechanism by which gentamicin-induced nephrotoxicity is unknown, however, several investigators reported that aminoglycoside antibiotics are a class of drug capable of causing the formation of ROS which can be directly involved in GM-induced damage (Kadkhodaee et al., 2005; Karahan et al., 2005).

Under normal conditions, ROS, which are generated during cellular functions, are eliminated by intrinsic antioxidant enzyme systems like superoxide dismutase and catalase (Kaul et al., 1993). It was postulated that aminoglycoside induced free radical generation and alteration in antioxidant enzyme activities may be the cause of tissue injury (Noorani et al., 2011). Montserrat et al. (2007) reported similar results as that of the current study concerning the reduced activity of superoxide dismutases (SOD) and catalase (CAT) in different tissues. Furthermore, PedrazaChaverri et al. (2000) and Maldonado et al. (2003) documented the induction of deficiency in antioxidant defense enzymes like superoxide dismutase and catalase. Karadeniz et al. (2008), attributed the cause of inactivation of antioxidant enzymes such as SOD to the increased production of ROS in GM-induced nephrotoxicity. Therefore, different superoxide dismutase treatments were shown to be effective in ameliorating renal injury in GM-induced nephrotoxicity (Cuzzocrea et al., 2002).

These biochemical findings correlated well with the renal histological examina- 
tion which revealed renal tubular necrosis and interstitial nephritis by light microscope. The electron microscopic study of kidney specimens from $G M$ injected rats revealed features of cell injury in proximal convoluted tubules, These features include cytoplasmic edema and vacuolization, mitochondrial disruption, increased number of lysosomes, disappearance of microvilli and aggregation of nuclear chromatin (apoptotic nucleus).

These pathological changes could be confirmed by Wiland and Szechcinski, (2003) who stated that the proximal tubular cells are a major target of damage in patients treated with GM. Gentamicininduced nephrotoxicity is structurally associated with the occurrences of cellular desquamation, glomerular atrophy, tubular necrosis, tubular fibrosis, epithelial oedema of proximal tubules, glomerular hypertrophy, perivascular edema and inflammation and glomerular congestion (Bledsoe et al., 2006; Lakshmi and Sudhakar 2010). On the other side, the present study did not reveal glomerular affection similar to the results of Kadkhodaee et al. (2005). In their study the glomeruli displayed no significant changes detectable by light microscopy, but there were signs of tubular damage including loss of brush borders, tubular debris and vast cellular vacuolations.

The mechanism by which GM induced tissue injury at cellular level was explained by Sandhu et al. (2007). They reported that gentamicin is a strongly cationic drug that binds to the negatively charged acidic components of the brush border membrane of the proximal tubule. They act on the cationic drug receptor, megalin, located deeply at the base of the brush border villi. The receptor-drug complex thus formed is rapidly taken up by lysosomes, where lysosomal phospholipidosis occurs that disrupts a number of renal intracellular processes. This mechanism explains the result of the current study concerning the increase in lysosomal bodies in electron microscopical study. Similar studies of El Mouedden et al. (2000) and Bledsoe et al. (2006) suggested that lysosomal phospholipidosis and apoptosis have been play a key role in gentamicin-induced nephrotoxicity. Moreover, gentamicin has been shown to cause changes in the composition of lipid membranes executed by free radicalsmediated lipid peroxidation (Parlakpinar et al., 2005).

In the present study, the combined administration of $\mathrm{GM}+\mathrm{NS}$ to rats resulted in significant reduction in the elevated levels of, BUN, serum creatinine and urinary protein excretion and significant increase in SOD and CAT tissue levels when compared with GM given rats. In addition, NS showed protective effect on kidney from GM induced lesions in proximal convolut- 
ed tubules in light and electron microscopic studies.

Bayrak et al. (2008) reported that the impaired renal functions indicating acute renal failure and histopathological changes are inhibited by nigella sativa oil. Moreover, antioxidant enzyme status in ischemic kidney is improved by nigella sativa oil treatment. Similarly, other reports (Ali, 2004; Ahmed and Nagi, 2007) found histopathological protective effects of NS or its component for induced nephrotoxicity of aminoglycosides including GM. In addition, Zaoui et al. (2002) reported no significant histopathological modifications in organs (heart, liver, kidneys and pancreas) of NS-treated rats.

The renoprotective effect of nigella sativa oil could be attributed to the improvement of the antioxidant status of the animals (Kanter et al., 2004; Hosseinzadeh et al., 2007) or the presence of free radical scavenging substances (Saleh et al., 2000) The latter authors also showed that nigella sativa oil given to sensitized guinea pigs inhibited free radical generation and increased serum levels of SOD and glutathione. Medenica et al. (1997) and Badary et al. (2000) confirmed that nigella sativa oil is an effective free radical scavenger showing antioxidant activity and protecting against the damage caused by oxidative stress. Therefore, the oil is useful in diseases, in which free radicals are involved.

\section{CONCLUSION}

The present study confirmed the toxic effect of gentamicin on kidney. The use of nigella sativa in combination with gentamicin could ameliorate its toxicity.

\section{RECOMMENDATION}

Gentamicin treatment should be done with caution with pre and post evaluation of renal function. Addition of nigella sativa treatment could be advised to minimize the renal side effect of gentamicin. 
Table (1): Statistical comparison between the mean values of all studied biochemical parameters of the negative control, saline and corn oil groups by ANOVA test.

\begin{tabular}{|l|c|c|c|c|c|}
\hline \multirow{2}{*}{ Parametcr } & \multicolumn{3}{|c|}{ Mean \pm SD } & & \\
\cline { 2 - 4 } & $\begin{array}{c}- \text { ve control } \\
\text { group } \\
\text { No=10 rats }\end{array}$ & $\begin{array}{c}\text { Saline } \\
\text { group } \\
\text { No=10 rats }\end{array}$ & $\begin{array}{c}\text { Corn oil } \\
\text { group } \\
\text { No=10 rats }\end{array}$ & $\begin{array}{c}\text { F- } \\
\text { Value }\end{array}$ & $\begin{array}{c}\text { P- } \\
\text { Value }\end{array}$ \\
\hline $\begin{array}{c}\text { BUN } \\
\text { (mg/ d) }\end{array}$ & $22.312 \pm 4.013$ & $22.86 \pm 3.66$ & $23.77 \pm 3.29$ & 1.48 & 0.242 \\
\hline $\begin{array}{c}\text { Creatinine } \\
\text { (mg/ dl) }\end{array}$ & $0.23 \pm 0.039$ & $0.23 \pm 0.044$ & $0.22 \pm 0.03$ & 0.01 & 0.99 \\
\hline $\begin{array}{c}\text { Urinary Protein } \\
\text { Excretion (mg/24hs) }\end{array}$ & $11.73 \pm 2.27$ & $11.4 \pm 1.31$ & $11.21 \pm 2.1$ & 0.37 & 0.697 \\
\hline $\begin{array}{c}\text { SOD in renal tissue } \\
\text { (U/mg protein) }\end{array}$ & $17.58 \pm 1.63$ & $16.91 \pm 1.88$ & $17.23 \pm 1.65$ & 0.65 & 0.53 \\
\hline $\begin{array}{c}\text { CAT } \\
\text { (K/mg protein) }\end{array}$ & $0.46 \pm 0.08$ & $0.45 \pm 0.06$ & $0.5 \pm 0.053$ & 0.11 & 0.897 \\
\hline
\end{tabular}

* Significance $=p<0.05 \quad \mathrm{No}=$ number

$\mathrm{K}=\mathrm{Katal}$ : International unit for expression of enzyme activities

Table (2): Statistical comparison between the mean values of all studied biochernical parameters of the negative control, nigella sativa, gentamicin and gentamicin+nigella sativa groups by ANOVA test.

\begin{tabular}{|c|c|c|c|c|c|c|}
\hline \multirow[b]{2}{*}{ Parameter } & \multicolumn{4}{|c|}{ Mean \pm SD } & \multirow[b]{2}{*}{$\begin{array}{c}\text { F- } \\
\text { Statstic }\end{array}$} & \multirow{2}{*}{$\begin{array}{c}\text { P- } \\
\text { Value }\end{array}$} \\
\hline & $\begin{array}{c}\text {-ve control group } \\
\mathrm{No}_{0}=10 \text { rats }\end{array}$ & $\begin{array}{c}\text { NS } \\
\text { group } \\
\mathrm{No}^{2}=10 \mathrm{rats}\end{array}$ & $\begin{array}{c}\text { GM } \\
\text { group } \\
\mathrm{No}=10 \mathrm{rats}\end{array}$ & $\begin{array}{c}\text { GM+NS } \\
\text { group } \\
\mathrm{No}_{0}=10 \mathrm{rats}\end{array}$ & & \\
\hline $\begin{array}{l}\text { BUN } \\
(\mathrm{mg} / \mathrm{dl})\end{array}$ & $22.312 \pm 4.013$ & $23.74 \pm 3.305$ & $56.45 \pm 3.29$ & $34.96 \pm 3.38$ & 711.34 & $0.000^{*}$ \\
\hline $\begin{array}{l}\text { Creatinine } \\
(\mathrm{mg} / \mathrm{dl})\end{array}$ & $0.23 \div 0.039$ & $0.24 \pm 0.039$ & $2.047 \pm 0.12$ & $0.569 \pm 0.052$ & 119.66 & $0.000^{*}$ \\
\hline $\begin{array}{l}\text { UrInary Protein } \\
\text { Excretion (mg/24hs) }\end{array}$ & $11.73 \pm 2.27$ & $11.02 \pm 0.96$ & $74.2 \pm 5.63$ & $25.64 \pm 3.18$ & 2951.28 & $0.000^{*}$ \\
\hline $\begin{array}{r}\text { SOD in renal tissue } \\
\text { (U/ing protein) }\end{array}$ & $17.58 \pm 1.63$ & $18.33 \pm 2.5$ & $7.34 \pm 2.24$ & $15.09 \pm 3.26$ & 104.87 & $0.000^{*}$ \\
\hline $\begin{array}{l}\text { CAT } \\
\qquad(K / \mathrm{mg} \text { protein) }\end{array}$ & $0.46 \pm 0.08$ & $0.452 \pm 0.06$ & $0.163 \pm 0.05$ & $0.376 \pm 0.058$ & 3.21 & $0.033^{*}$ \\
\hline
\end{tabular}

*Significance $=p<0.05$

No= number

$\mathrm{K}=\mathrm{Katal}$ : International unit for expression of enzyme activities 
Table (3): Least Significant Difference (LSD) for comparison between the mean values of all studied biochemical parameters of the negative control, negella sativa, gentamicin and gentamicin+negella sativa groups.

\begin{tabular}{|c|c|c|c|c|c|c|c|c|c|c|}
\hline & \multicolumn{2}{|c|}{$\begin{array}{c}\text { BUN } \\
(\mathrm{mg} / \mathrm{dl})\end{array}$} & \multicolumn{2}{|c|}{$\begin{array}{l}\text { Creatinine } \\
(\mathrm{mg} / \mathrm{dl})\end{array}$} & \multicolumn{2}{|c|}{$\begin{array}{c}\text { Urinary Protein } \\
\text { Excretion } \\
\text { (mg/24hs) }\end{array}$} & \multicolumn{2}{|c|}{$\begin{array}{l}\text { SOD in renal } \\
\text { tissue } \\
\text { (U/mg protein) }\end{array}$} & \multicolumn{2}{|c|}{$\begin{array}{c}\text { CAT } \\
(K / \mathrm{mg} \text { protcin })\end{array}$} \\
\hline & $t$ & $\bar{p}$ & $\bar{t}$ & $p$ & $T$ & $P$ & $t$ & $P$ & $t$ & $P$ \\
\hline$P_{1 \text { (I\&IV) }}$ & 1.41 & 0.109 & 0.22 & 0.911 & 1.16 & 0.225 & 1.11 & $\begin{array}{c}0.25 \\
5 \\
\end{array}$ & 0 & 0.946 \\
\hline$P_{2(I \& V)}$ & 11.69 & 0.000 & 5.92 & 0.000 & 17.03 & 0.000 & 6.47 & $\begin{array}{c}0.00 \\
0\end{array}$ & 1.92 & 0.014 \\
\hline $\mathbf{P}_{\mathbf{3} \text { (I\&VI) }}$ & 6.004 & 0.000 & 2.33 & 0.001 & 7.08 & 0.000 & 2.33 & $\begin{array}{c}0.00 \\
1\end{array}$ & 0.79 & 0.482 \\
\hline$P_{\text {A(IV\&V) }}$ & 11.75 & 0.000 & 5.89 & 0.000 & 4.27 & 0.000 & 6.26 & $\begin{array}{c}0.00 \\
0\end{array}$ & 2.001 & 0.009 \\
\hline$P_{5 \text { (IV\&VI) }}$ & 2.64 & 0.000 & 2.28 & 0.002 & 8.02 & 0.000 & 2.63 & $\begin{array}{c}0.00 \\
0 \\
\end{array}$ & 0.80 & 0.484 \\
\hline$P_{6(V \& V I)}$ & 8.85 & 0.000 & 5.03 & 0.000 & 13.88 & 0.000 & 4.78 & $\begin{array}{c}0.00 \\
0\end{array}$ & 1.77 & 0.03 \\
\hline
\end{tabular}

*: Significant $(\mathrm{P}<0.05) \quad \mathrm{K}=$ Katal : International unit for expression of enzyme activities

$Y=-v e$ control group

$\mathbf{I V}=$ Nigeila sativa grous

$\mathbf{V}=$ Gentamicin group

$\mathrm{VI}=$ Nigella sativa + gentamicin group

$P_{1}=$ comparison between group $1 \& 4$

$\mathrm{P}_{2}=$ comparison between group I \& $S$

$\mathbf{P}_{3}=$ comparison between group 1 \& 6

$P=$ comparison between group $4 \& 5$

$\mathbf{P}_{5}=$ comparison between group $4 \& 6$

$P_{6}=$ comparison between group $S \& 6$ 


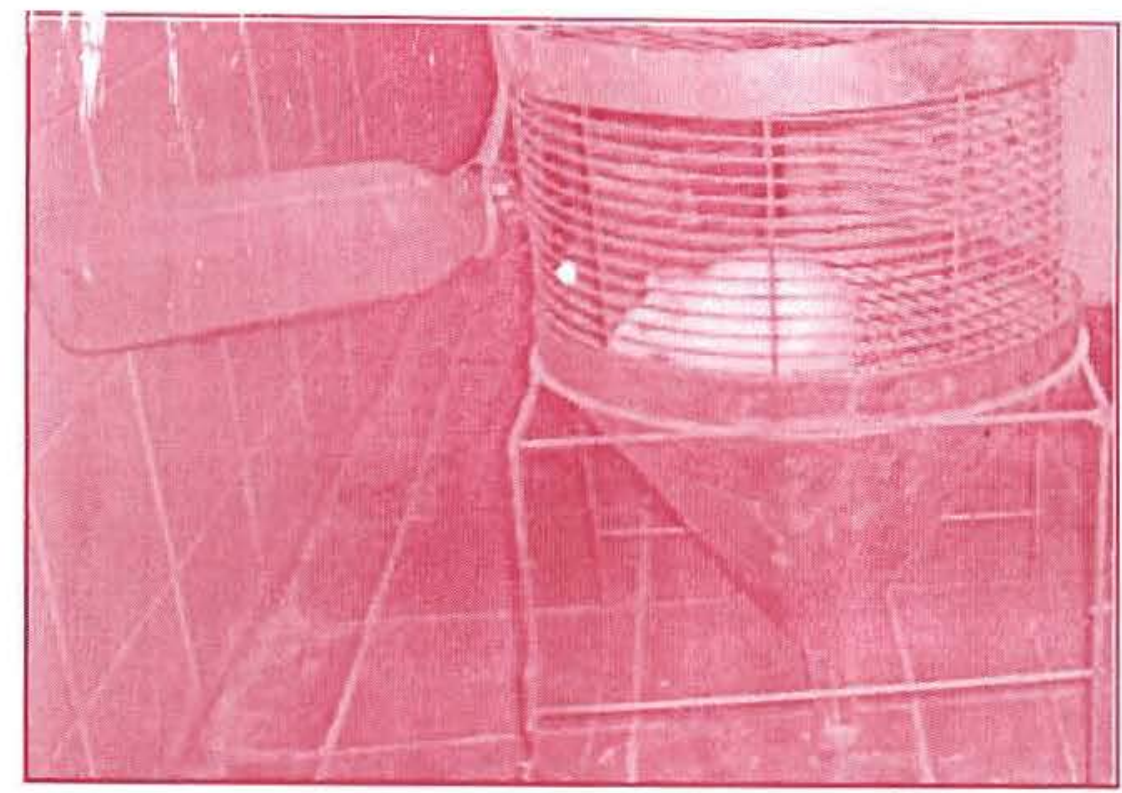

Figure (1): A photomicrograph of a metabolic cage showing the urine collection in the tube (arrow).

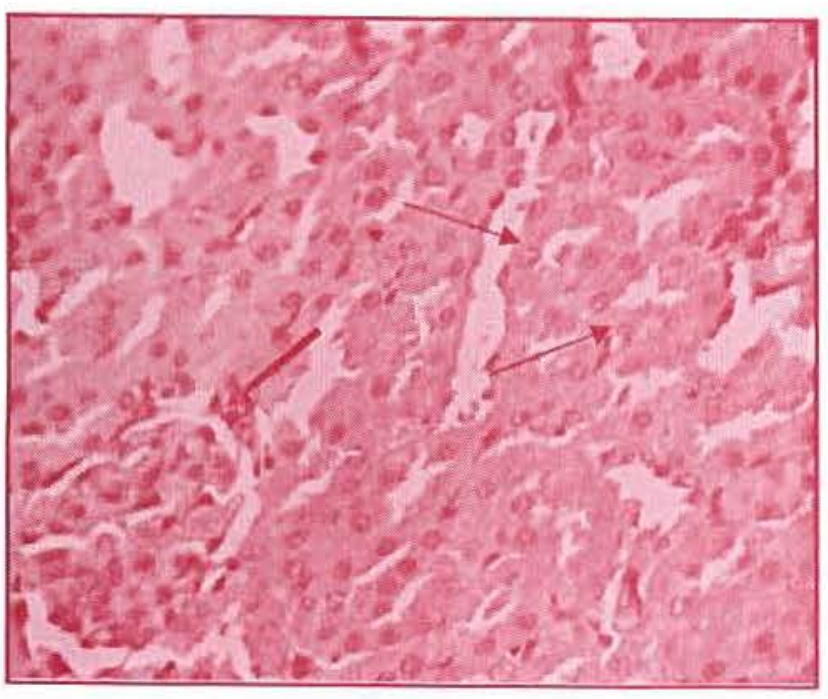

Figure (2): A photomicrograph of a section in kidney of -ve controt rat showing normal listological features; glomerulous (thick arrow) and proximal convoluted tubules (thin arrow) (H\&EX200).

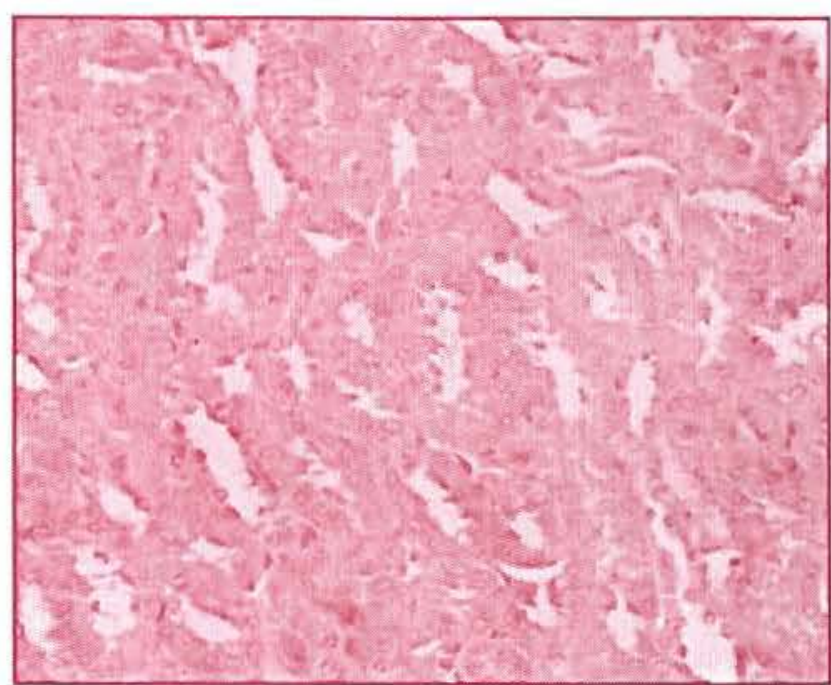

Figure (3): A photomicrograph of a section in kidney of -ve control rat showing normal proximal convoluted tubules (H\&EX150). 


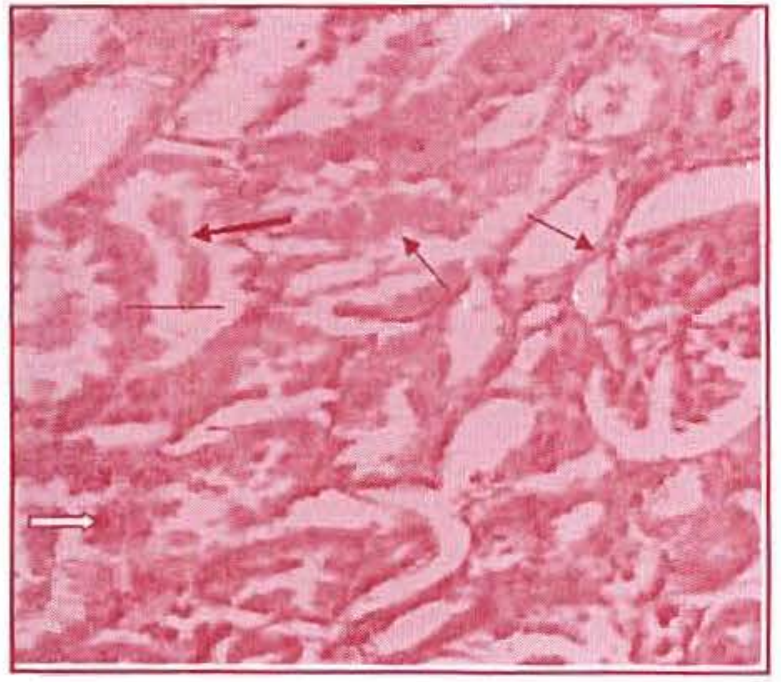

Figure (4): A photomicrograph of a section in kidney of GM given rat showing loss of normal architecture of proximal convoluted tubules, degenerated cells (line), apoptotic nuclei (white arrow) and cellular necrosis (thin arrow) and tubular debris in the lumen (thick ar-

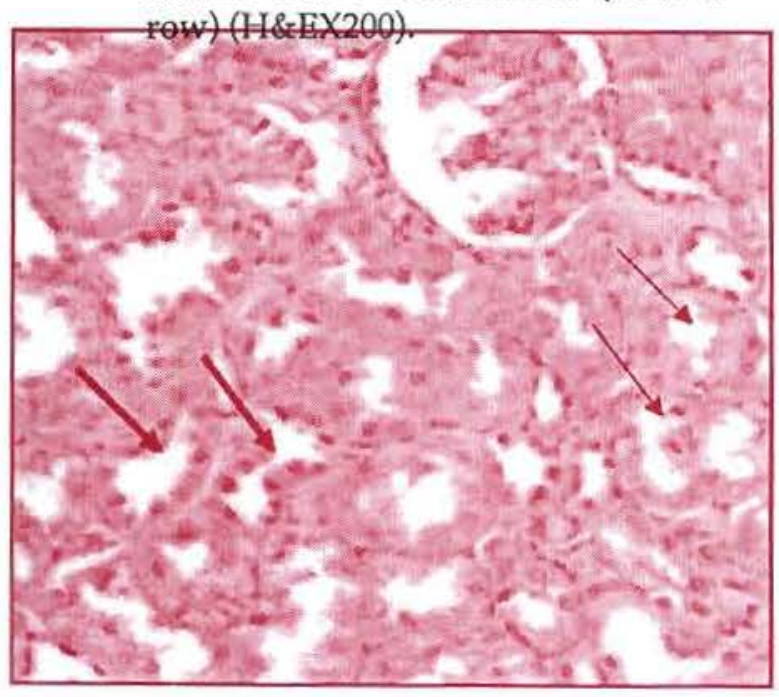

Figure (6): A photomicrograph of a section in kidney of combined GM+NS given rat showing tubules with normal architecture (thick arrow) and some destructed tubules (thin arrow) (H\&EX200).

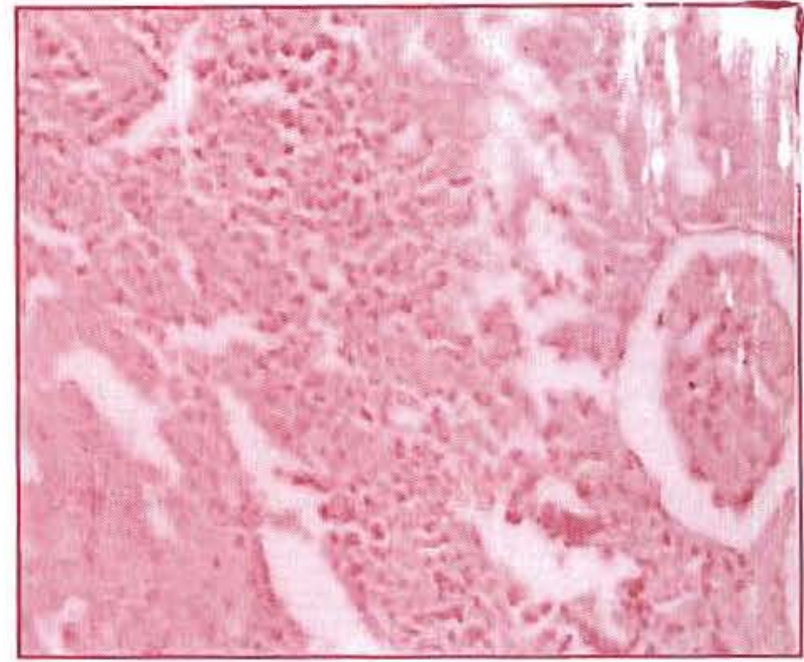

Figure (5): A photomicrograph of a section in kidney of -ve control rat showing normal proximal convoluted tubules (H\&EX150).

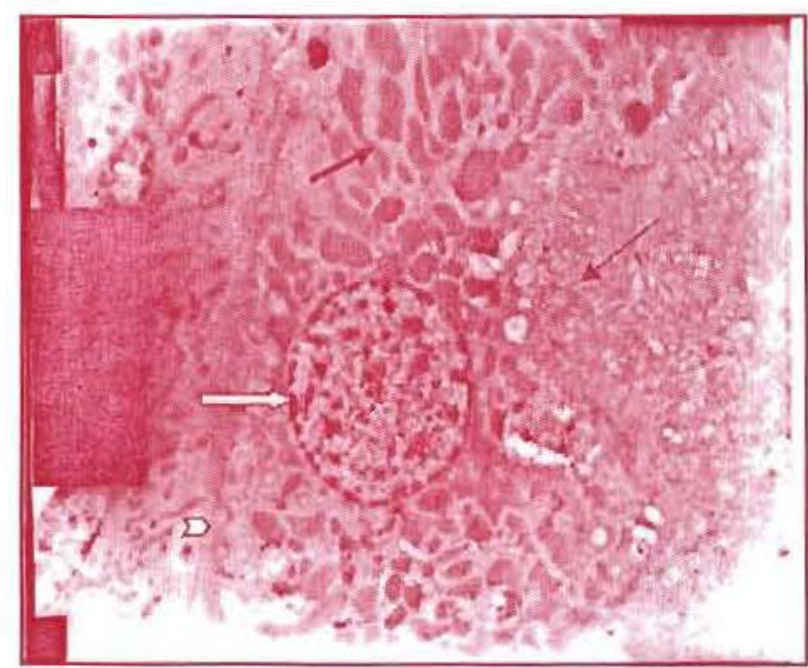

Figure (7): A transmission electron micrograph of a section in kidney of -ve control rat showing epithelial cells lining a proximal convoluted tubule with large rounded euchromatic nucleus (white arrow), apical microvilli (thin arrow) and many mitochondria (thick arrow). Note thin basal membrane (white arrow head) (EM X 3000). 


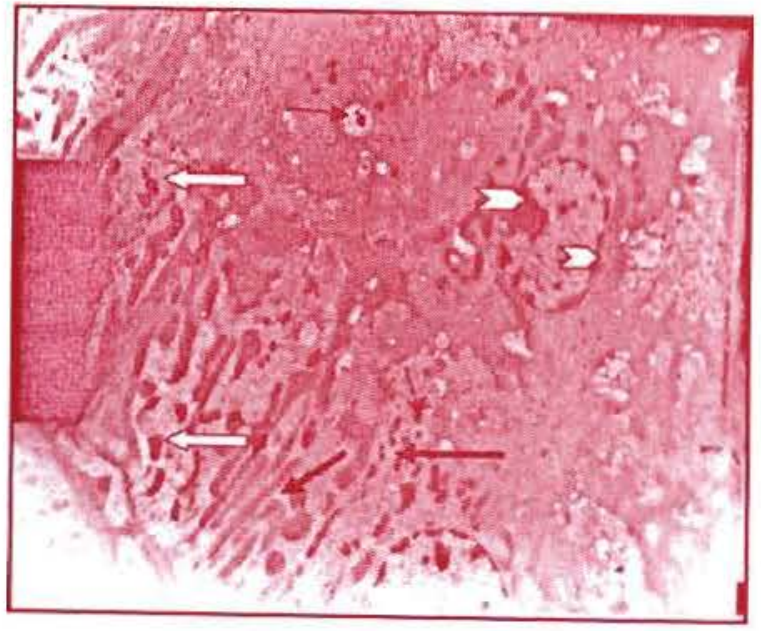

Figure (8): A transmission electron micrograph of a section in kidney of GM given rat showing epithelial cells lining a proximal convoluted tubule with lysosomal dense bodies of variable sizes (white arrow), degenerated and disorganized mitochondria (thick arrow) and the nucleus show margination of chromatin (white arrow head) Note: appearance of endocytic vacuoles that contain round electron dense bodies (thin arrow) (EM X 3000).

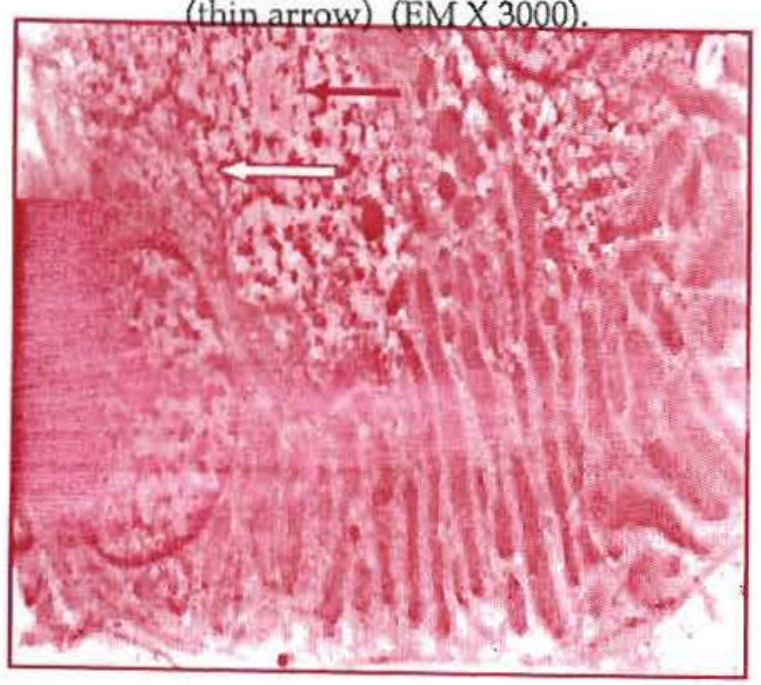

Figure (10): A transmission electron micrograph of a section in kidney of GM given rat showing other convoluted tubule with loss of microvilli (white arrow) and cellular debris in the lumen (thick arrow). (EM X 3000).

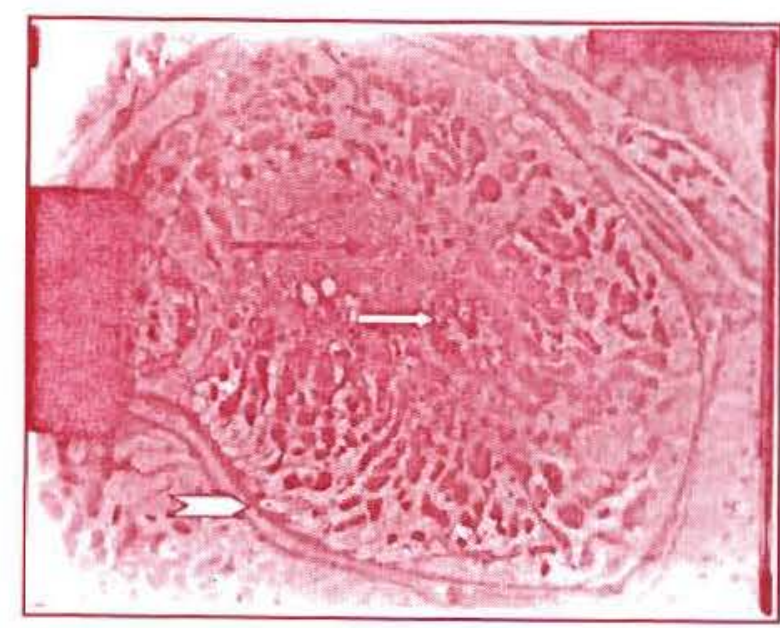

Figure (9): A transmission electron micrograph of a section in kidney of GM given rat showing destructed proximal convoluted tubule with obliterated lumen (thick arrow). The tubular epithelium shows electron dense apoptotic nucleus (white arrow). Note: thick basal membrane (white arrow head) (EM X 3000).

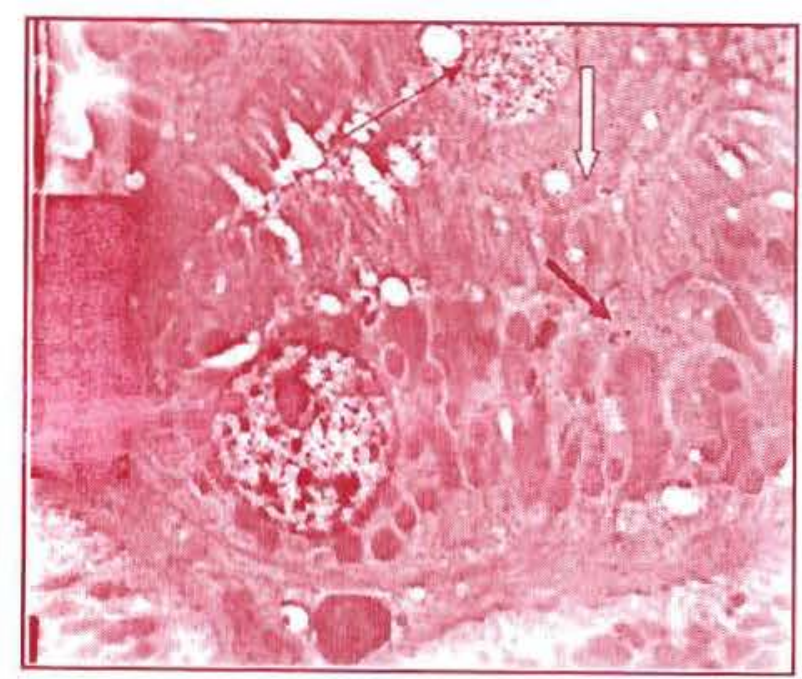

Figure (11): A transmission electron micrograph of a section in kidney of combined GM+NS given rat showing proximal convoluted tubule with euchromatic nucleus, long apical microvilli ((white arrow), many mitochondria (thick arrow) and some cellular debris in the lumen (thin arrow). (EM X 3000). 


\section{REFERENCES}

Ahmed, S. M. M. and Nagi, N. (2007) : "Thymoquinone supplementation prevents the development of gentamicininduced acute renal toxicity in rats". Clin. Exp. Pharmacol. Physiol., 34: 399-405.

Ali, B. H. (2003) : "Agents ameliorating or augmenting experimental gentamicin nephrotoxicity: some recent research". Food Chem. Toxicol., 41: 1447-1452.

Ali, B. H. (2004) : "The effect of Nigella sativa oil on gentamicin nephrotoxicity in rats". Am. J. Chin. Med., 32: 49-55.

Ali, B. H. and Blunden, G. (2003) : "Pharmacological and toxicological properties of Nigella sativa". Phytother. Res., 17: 299-305.

Atessahin, A.; Karahan, I.; Yilmaz, S.; Ceribasi, A. O. and Princci, I. (2003) : "The effect of manganese chloride on gentamicine-induced nephrotoxicity in rats". Pharmacol. Res., 48: 637-642.

Badary, O. A.; Abdel-Naim, A. B.; Abdel-Wahab, M. H.; et al.; (2000) : "The influence of thymoquinone on doxorubicininduced hyperlipidemic nephropathy in rats". Toxicology, 143: 219-226.

Bancroft, G. D. and Stevens, A. (1996) : Theory and Practice of Histological Tech- nique. $4^{\text {th }}$ edition, Churchill Livingstone Edinburgh, Melbourne and New York, P.P 99-112.

Bayrak, O.; Bavbek, N.; Karatas1, O.F; Bayrak, R.; Catal, F.; Cimentepe, E., Akbas, A.; Yildirim, E.; Unal, D. and Akcay, A. (2008): "Nigella sativa protects against ischaemia/reperfusion injury in rat Kidneys". Nephrol. Dial. Transplant, 23: 22062212.

Bledsoe, G.; Crickman, S.; Mao, J.; Xia, C.F.; Murakami, H.; Chao, L.; et al. (2006): "Kallikrein/kinin protects against gentamicin-induced nephrotoxicity by inhibition of inflammation and apoptosis". Nephrol. Dial. Transplant, 21:624-633.

Bonsens, R. W. and Taussky, H. M. (1945) : "On the colorimetric determination of creatinine by the Jaffk reaction". Journal of Biological Chemistry, 158: 581-591.

Burits, M. and Bucar F. (2000) : "Antioxidant activity of Nigella sativa essential oil". Phytother. Res., 14: 323-328.

Claiborne, A. (1985) : Handbook of Methods for Oxygen Radical Research. In: Catalase Activity, Boca Raton, Florida, P.P. 283-284.

Cuzzocrea, S.; Mazzon, E.; Dugo, L.; Serraino, I.; Di Paola, R.; Britti, D.; De Sarro, A.; Pierpaoli, S.; Caputi, A.; 
Masini, E. and Salvemini, E. (2002) : "A role for superoxide in gentamicinmediated nephropathy in rats". Eur. J. Pharmacol., 450(1):67-76.

Dean, A; Coulombier, D. and Brendel, K. (1994) : Epi-info version 6: word processing database statistics program for public health CDC, USA.

El Mouedden, M.; Laurent, G.; Mingeot-Leclercq, M. P.; Taper, H. S.; Cumps, J. and Tulkens, P. M. (2000) : "Apoptosis in renal proximal tubules of rats treated with low doses of aminoglycosides". Antimicrob. Agents Chemother., 44:665-675.

Glauert, A. and Lewis, P. (1998) : Biological Specimen Preparation for Transmission Electron Microscopy. Volume 17 Portland Press London, P.P. 112-125.

Ho, J. L. and Barza, M. (1987) : "Role of aminoglycoside antibiotics in the treatment of intra-abdominal infection". Antimicrob. Agents Chemother., 31: 485-549.

Hosseinzadeh, H.; Parvardeh, S.; Asl, M. N.; et al. (2007): "Effect of thymoquinone and Nigella sativa seeds oil on lipid peroxidation level during global cerebral ischemia-reperfusion injury in rat hippocampus". Phytomedicine., 14(9): 621-627.

Juan, S. H.; Chen, C. H.; Hsu ,Y. H.; Hou, C. C.; Chen, T. H.; Lin, H.; Chu, Y.
L. and Sue, Y. M. (2007) : "Tetramethylpyrazine protects rat renal tubular cell apoptosis induced by gentamicin". Nephrol. Dial. Transplant, 22: 732-739.

Kadkhodaee, K.; Khastar, H.; Faghihi, M.; Ghaznavi, R. and Zahmatkesh, M. (2005) : "Effects of co-supplementation of vitamins $\mathrm{E}$ and Con gentamicin-induced nephrotoxicity in rat". Exp. Physiol., 90(4): 571-576.

Kanter, M.; Coskun, O.; Korkmaz, A. and Oter, S. (2004) : "Effects of Nigella sativa on oxidative stress and beta-cell damage in streptozotocin-induced diabetic rats". Anat. Rec. A. Discov. Mol. Cell Evol. Biol., 279(1): 685-691.

Kaplan, A. (1965) : Urea Nitrogen and Urinary Ammonia. In: Slandered Methods of Clinical Chemistery. Academic press, New York, 5: P.P. 245-256.

Karadeniz, A.; Yildirim, A.; Simsek, N.; Kalkan, Y. and Celebi, F. (2008) : "Spirulina platensis protects against gentamicin- induced nephrotoxicity in rats". Phytother. Res., 22: 1506-1510.

Karahan, I.; Atessahin, A.; Yilmaz, S.; Çeribas1, A. O. and Sakin, F. (2005): "Protective effect of lycopene on gentamicin-induced oxidative stress and nephrotoxicity in rats". Toxicology, 215 : 198204. 
Kaul, N.; Siveski-Iliskovic, N.; Hill, M.; Slezak, J. and Singal, P. K. (1993): "Free radicals and the heart". J. Pharmacol. Toxicol. Methods, 30: 55-67.

Lakshmi, B. V. S. and Sudhakar, M. (2010) : "Protective effect of zingiber officinale on gentamicin- induced nephrotoxicity in rats". Int. J. Pharmacol., 6:5862.

Maldonado, P. D.; Barrera, D.; Medina-Campos, O. N.; Hernández-Pando, R.; Ibarra-Rubio, M. E. and PedrazaChaverri, J. (2003) : "Aged garlic extract attenuates gentamicin induced renal damage andoxidative stress in rats". Life Sci., 73 (20): 2543-2556.

Marklund, S. L. (1985) : "Superoxide dismutase isoenzymes in tissues and plasma from New Zealand black mice, nude mice and normal BALB/c mice". Mutat. Res., 148: 129-134.

Medenica, R.; Janssens, J. and Tarasenko, A. (1997) : "Anti-angiogenic activity of Nigella sativa plant extract in cancer therapy". Proceedings Annual Meeting of the American Association for Cancer Research, 38: 1377.

Montserrat, B.; Victoria, L. and Albina, M. L. (2007) : "Melatonin reduce uraniuminduced nephrotoxicity in rats". J. Pineal. Res., 43:87.-95.
Morales, A. I.; Buitrago, J. M.; Santiago, J. M.; Fernández-Tagarro, M.; LópezNovoa, J. M. and Pérez-Barriocanal, F. (2002): "Protective effect of trans-resveratrol on gentamicin-induced nephrotoxicity".Antioxid. Redox Signal., 4:893-898.

Nishi, H. H. and Elin, R. J. (1985) : "Three turbidimetric methods for determining total protein compared". Clin. Chem., 31: 1377-1380.

Noorani, A. A.; Gupta, K.; Bhadada, K. and KALE, M. K. (2011) : "Protective effect of methanolic leaf extract of Caesalpinia Bonduc (L.) on gentamicin-induced hepatotoxicity and nephrotoxicity in rats". Iranian Journal of Pharmachology \& Therapeutics, 10: 21-25.

Parlakpinar, H.; Tasdemir, S.; Polat, A.; Bay-Karabulut, A.; Vardi, N.; Ucar, M.; et al. (2005): "Protective role of caffeic acid phenethyl ester (cape) on gentamicininduced acute renal toxicity in rats". Toxicology, 207:169-177.

Pedraza-Chaverrí, J.; Barrera, D.; Maldonado, P. D.; Chirino, Y. I.; PedrazaChaverrí, J.; González-Orozco, A. E.; Maldonado, P. D.; Barrera, D.; MedinaCampos, O. N. and Hernández-Pando, R. (2003): "Diallyl disulfide ameliorates gentamicin-induced oxidative stress and nephropathy in rats". Eur. J. Pharmacol., 473: 71-78. 
Pedraza-Chaverri, J.; Maldonado, P. D.; Medina-Campos, O. N. OlivaresCorichi, I. M.; Granados-Silvestre, M.A.; Hernandez-Pando, R.; et al. (2000) : "Garlic ameliorates gentamicin nephrotoxicity: relation to antioxidant enzymes". Free Radic. Biol. Med., 29:602-611.

Phillips, J. D. (1992) : "Medicinal plants". Biologist., 39:187-191.

Robbins, G. R.; Castellano, R. F.; Torning, F. E.; Fabry, A. and Fieldex, F. G. (1971) : "Acute toxicity in rats (intramuscular, intravenous and intraperitoneal) and mice (intramuscular, intravenous, intraperitoneal and subcutaneous)". Unpublished Report, P. 3967. Submitted to WHO by Inveresk Research International, Trenant, Scotland, on behalf of Schering Plough Animal Health.

Safa, J.; Argani, H.; Bastani, B.; Nezami, N.; Ardebili, B. R.; Ghorbanihaghjo, A.; Kalagheichi, H.; Amirfirouzi, A.; Mesgari, M. and Rad, J. S. (2010) : "Protective effect of grape seed extract on Gentamicin- induced acute kidney injury". Iran J. Kidney. Dis., 4: 285-291.

Saleh, S.; El-Denshary, E. M. S.; Mahran, L. G.; et al. (2000) : "Antiinflammatory and antioxidant effects of Nigella sativa oil in sensitized animals". $25^{\text {th }}$ International Conference on Science and Technology, New Delhi, India.

Sandhu, J. S.; Sehgal, A.; Gupta, O. and Singh, A. (2007): "Aminoglycoside nephrotoxicity revisited". J. Ind. Acad. Clin. Med., 8:331-333.

Silan, C.; Uzun, O.; Comunog $\ u, N$. U; Gokçen, S.; Bedirhan, S. and Cengiz, M. (2007) : "Gentamicin-induced nephrotoxicity in rats ameliorated and healing effects of resveratroI". Biol. Pharm. Bułl., 30: 79-83.

Soliman, K. M.; Abdul-Hamid, M. and Othman, A. I. (2007) : "Effect of carnosine on gentamicin- induced nephrotoxicity". Med. Sci. Monit., 13: 73-83.

Wiland, P. and Szechcinski, J. (2003): "Proximal tubule damage in patients treated with gentamicin or amikacin". Pol. J. Pharmacol., 55 : 631637.

Yanagida, C.; Ito, K.; Komiya, I. and Horie, T. (2004) : "Protective effect of fosfomycin on gentamicin-induced lipid peroxidation of rat renal tissue". Chem. Biol. Interact., 148 (3): 139-147.

Zager, R. A. (2007) : "Subclinical gentamicin nephrotoxicity: a potential risk factor for exaggerated endotoxin-driven TNF- production". Am. J. Physiol. Renal Physiol., 293: 43-49. 
Zaoui, A.; Cherrah, Y.; Alaoui, K.; Mahassine, N.; Amarouch, H. and Hassar, N. (2002): "Effects of Nigella sativa fixed oil on blood homeostasis in rat". J. Ethnophrmacol., 79 (1):23-26.
Zaoui, A.; Cherrah, Y.; Mahassini, N.; Alaoui, K.; Amarouch, $\mathrm{H}$. and Hassar, N. (2002): "Acute and chronic toxicity of Nigella sativa fixed oil". Phytomedicine, 9:69-74. 


\title{
التأثبيرات السا مة للجينتا ميسين على الكلية والقيهة الوقائية لإضافة حبة

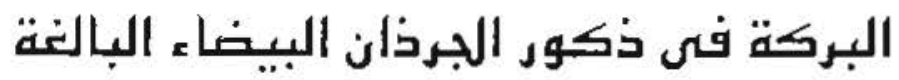

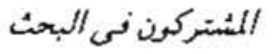 \\ د. هدى رجب السيد . زينب عبد الرحيهم"

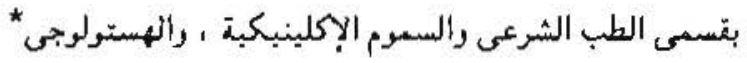 \\ كلية الطب جامعة الزتازيق
}

الجبنتاميسين هو مضاد حيوى فعال ضد العدوى بالبكتريا سالبة المجرام رولكن له تأثير سام على الكلى فى الإنسان . رتد أجرى العديد من الأبحاث رالتحاليل على زيت حبة البركة والتى كثفت عن نشاطه كمضاد للاككسة فى ظروف مـختلفة. والهذف من هذه الدراسة هو تَبيبم

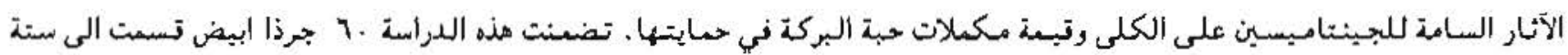

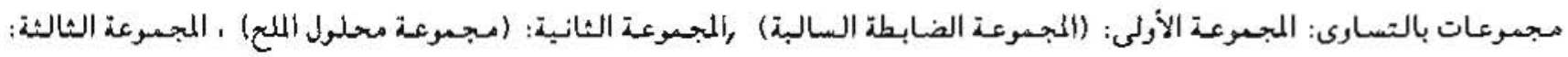
(مجموعة زيت الذرة) ، المجموعة الرابعة: (مبموعة جبة البركة) ، المجعوعة الخامسة: (مجموعة المبينتاميسين) ، المجموعة السـادسة: (مجموعة الجبينتاميسين+ حبة البركة) . وتد إستمرت هذه الدراسة لمدة عشرة أيام ، ونى آخر ع باعة تم تجمبع البول لقياس نسبة إفراز البروتين روبعد ذلك أستخدمت الجرذان لتياس نسبة اليوريا والكرياتبنين فى الدم ونسبة الديسموناز والكاتلازنى نسيج الكلى، ولدراسة التأثير ألهستوباثولوجى على المكلى بالمجهر الضونى والإلكترونى ، وتد أوضحت هذه الدراسة عدم وجود فرق ذر دلالة إحصاتبة هين المجسوعات الضابطة السـالبة رمجموعة محلول الملح ومجعوعة الزيت وكذلك مجموعة حبة البركة نى جميع القياسات البيوكيميانية ربينما هناك نرق ذر دلالة إحصانبة بين مجموعة المبينتاميسين و المجموعة الضابطة السالة ، كما رجد أبضا نرت ذر دلالة إحصائية بين مجموعة الجينتاميسين عند مقارنتها مع مجموعة الجينتاميسين+ حبة البركة وذلك نيما بخص جميع القياسات الببوكبمبانية. وتد أظهر نحص المكلى لجرذان مسجوعة الجينتامبسين بالمجهر الضوئى تنكس الأنابيب القريبة، والموت ألخلوى ، وتقشر خلايا ، وخلل فى بناء الأنابيب الكلرية ركذلك التسلل الإلتهابى • يبنما أظهر الفحص بالمجهر الإلكترونى التفاصيل الدتيقة للتغيرأت الهستوياثولوجبة التى ساعدت نى نفسبر آلية التسمم بهذا العنار ،

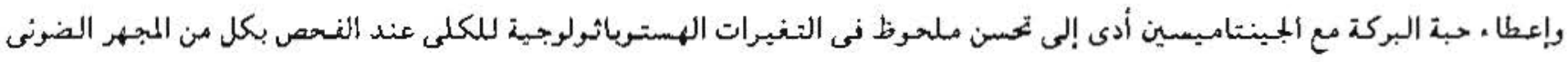
والإلكترونى ، ولهذا نقد أستنتج أن الجينتامبسين له تأثبر سام على الكلى وإستخدام حبة البركة مع الجنتاميسين أدى إلى تحسين هذا التسمب. 


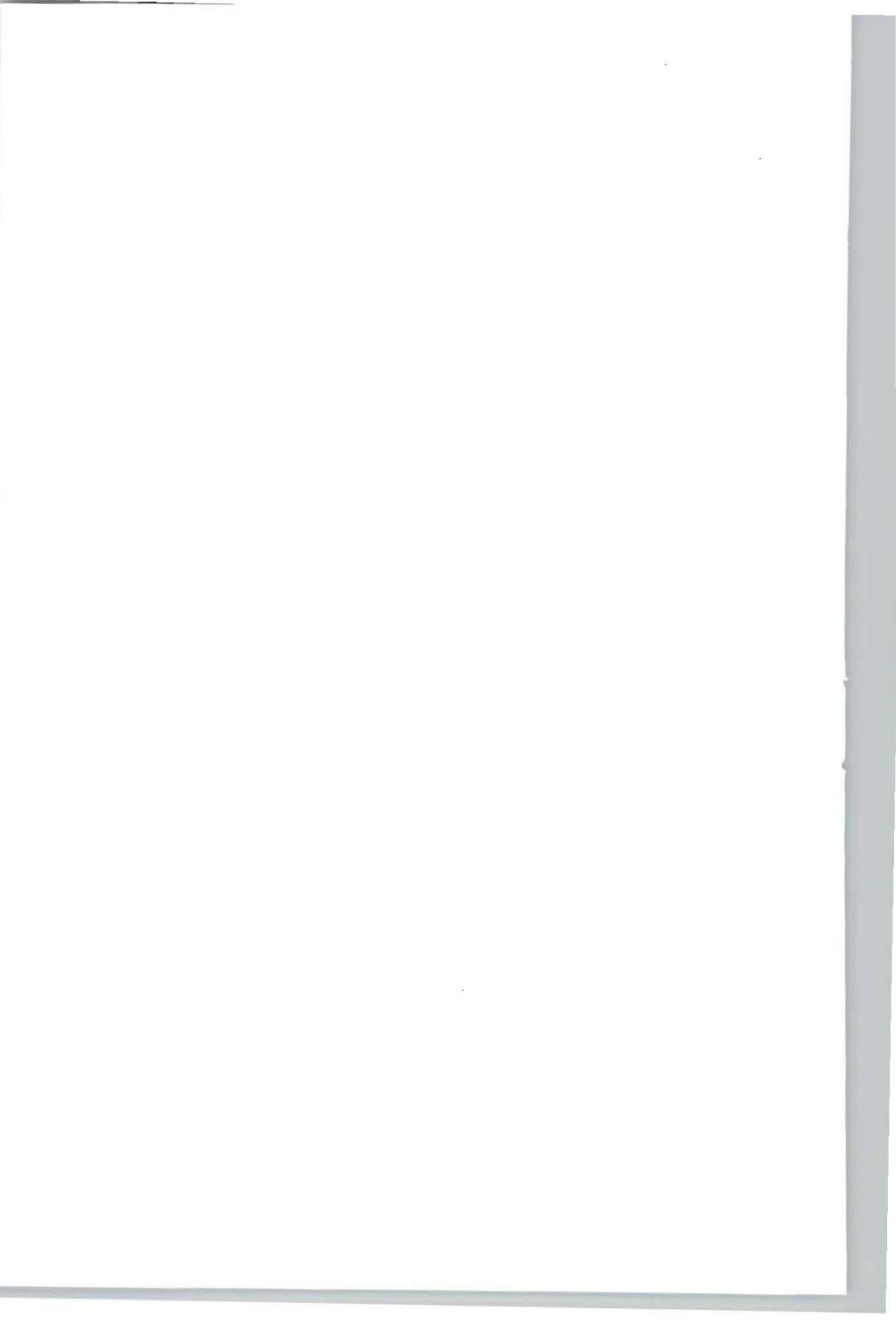

